\title{
Estimated microbial protein yield from the rumen of sheep given cottonseed cake or ensiled poultry manure
}

\author{
A. J. F. Webster ${ }^{1}$, M. E. Kitcherside ${ }^{1}$, E. F. Glen ${ }^{1}$ and N. Ngongoni ${ }^{2}$ \\ 'Department of Animal Husbandry, University of Bristol, Langford House, Langford, Bristol BS18 7DU \\ ${ }^{2}$ Department of Animal Science, University of Zimbabwe, Harare, Zimbabwe
}

\section{Introduction}

The metabolizable protein (MP) system (Webster, 1989) partitions rumen degradable nitrogen (RDN) into quickly and slowly degradable nitrogen, QDN and SDN respectively. It is assumed that SDN may be converted into microbial protein nitrogen (MiN) at an efficiency of 1.0 when fermentable energy is not limiting but for QDN the efficiency may be less than 1.0 .

Attempts to measure MiN using post-rumenal cannulae and microbial markers are invasive, expensive and slow. In recent years Chen, Hovell, $\varnothing$ rskov and Brown (1990) and Dewhurst and Webster (1992) have attempted to estimate MiN from urinary excretion of purine derivates (measured as allantoin, UAN). The results of Chen et al. (1990) suggest that when dietary intake exceeds maintenance the net contributions of endogenous purines and purine salvage are relatively constant so that increments of UAN can be equated with reasonable confidence to increments of MiN.

This approach is used here to relate $\mathrm{MiN}$ to intake of digestible dry matter (DDM) in sheep given diets in which crude protein was provided from ensiled poultry manure (EPM) and cottonseed cake (CSC) by-products chosen partly because of their importance to tropical agriculture and partly because they differ widely in the ratio QDN : SDN.

\section{Material and methods}

The composition of the two diets is shown in Table 1. The carbohydrate sources were wheat, starch and nutritionally improved straw so that EPM and CSC were overwhelmingly the main sources of dietary nitrogen. The ratios QDN : RDN were 0.88 and 0.44 for the EPM and CSC diets respectively. The ratios RDN : ME were designed to be approximately $1 \cdot 3: 1$ for both diets.
Table 1 Dict composition

\begin{tabular}{lcc}
\hline Composition & $\begin{array}{c}\text { Ensiled } \\
\text { poultry manure }\end{array}$ & $\begin{array}{c}\text { Cottonseed } \\
\text { cake }\end{array}$ \\
\hline $\begin{array}{l}\text { Estimated metabolizable energy } \\
\text { ME (MJ/kgDM) }\end{array}$ & 10.6 & 10.1 \\
Total nitrogen (N) (g/kgDM) & 18.3 & 26.5 \\
Quickly degradable N & 11.7 & 6.0 \\
Slowly degradable N & 1.6 & 7.7 \\
Rumen degradable & 1.26 & 1.36 \\
N : ME (g/MJ) &
\end{tabular}

Two trials were conducted each with 12 wether sheep. In trial 1, groups of three sheep were given the EPM and CSC at 800 and $1600 \mathrm{~g} /$ day, calculated to provide, on average, maintenance $\left(E_{m}\right)$ and twice maintenance $\left(2 E_{m}\right)$. In trial 2 , the same diets were given to six groups of two sheep in amounts calculated to provide $1.0 \times, 1.5 \times$ and $2.0 \times \mathrm{E}_{\mathrm{m}}$.

Each trial involved a 14-day adaptation period and 10-day total collections of urine and faeces. The autoanalyser method for measurement of urinary allantoin has been described by Dewhurst (1989).

\section{Results}

The most important mean values from trials 1 and 2 are given in Table 2 . In both trials urinary allantoin nitrogen (UAN) was closely related to intake of DDM $(\mathrm{g} /$ day). The relationship between intake of DDM and excretion of UAN was the same for diets based on EPM and CSC.

This relationship was examined by linear regression of UAN in DDM for individual sheep. There were no significant differences in regression coefficient between EPM and CSC. 
Table 2. Intakes of digestible dry matter (DDM), rumen degradable nitrogen (RDN) and urinary excretion of total nitrogen and allantoin nitrogent

\begin{tabular}{|c|c|c|c|c|c|c|}
\hline \multirow[t]{2}{*}{ Trial 1} & \multicolumn{3}{|c|}{ Ensiled poultry manure } & \multicolumn{2}{|c|}{ Cottonseed cake } & \\
\hline & $\mathbf{E}_{\mathbf{m}}$ & & $2 E_{m} t$ & $\mathbf{E}_{\mathbf{m}}$ & $2 E_{m} t$ & \\
\hline $\begin{array}{l}\text { Intake, DDM (g/day) } \\
\text { RDN (g/day) } \\
\text { Urinary N (g/day) } \\
\text { Urinary allantoin } N(\mathrm{mg} / \text { day })\end{array}$ & $\begin{array}{r}498 \\
9 \cdot 85 \\
9 \cdot 88 \\
405\end{array}$ & & $\begin{array}{c}1013 \\
22 \cdot 2 \\
11.7 t \\
1091 t\end{array}$ & $\begin{array}{c}502 \\
9.78 \\
13 \cdot 3 \\
461\end{array}$ & $\begin{array}{c}1117 \\
20 \cdot 1 \\
20 \cdot 6 t \\
1139 t\end{array}$ & \\
\hline \multirow[t]{2}{*}{ Trial 2} & \multicolumn{3}{|c|}{ Ensiled poultry manure } & \multicolumn{3}{|c|}{ Cottonseed cake } \\
\hline & $\mathbf{E}_{\mathbf{m}}$ & $1.5 \mathrm{E}_{\mathrm{m}}$ & $3 \mathrm{E}_{\mathrm{m}}$ & $\mathrm{E}_{\mathrm{m}}$ & $1.5 \mathrm{E}_{\mathrm{m}}$ & $2 \mathrm{E}_{\mathrm{m}}$ \\
\hline $\begin{array}{l}\text { Intake, DDM (g/day) } \\
\text { RDN (g/day) } \\
\text { Urinary N (g/day) } \\
\text { Urinary allantoin } N(m g / \text { day })\end{array}$ & $\begin{array}{c}451 \\
9.60 \\
11 \cdot 4 \\
599\end{array}$ & $\begin{array}{l}726 \\
14 \cdot 5 \\
12 \cdot 3 \\
852\end{array}$ & $\begin{array}{c}918 \\
19 \cdot 4 \\
14 \cdot 7 \\
1162\end{array}$ & $\begin{array}{l}526 \\
10 \cdot 1 \\
16 \cdot 0 \\
491\end{array}$ & $\begin{array}{l}745 \\
15 \cdot 3 \\
21 \cdot 3 \\
844\end{array}$ & $\begin{array}{c}908 \\
20 \cdot 3 \\
23 \cdot 9 \\
1237\end{array}$ \\
\hline
\end{tabular}

+ In each case the data for one sheep were unreliable and have been excluded.

The pooled regressions (no. $=22$ ) were as follows: (1) UAN (mg/day) =1.18 DDM (g/day) $-65 \cdot 5\left(\mathrm{~s} . e . b=0 \cdot 15 ; r^{2}=0.76\right)$. (2) UAN (mg $/ \mathrm{kg}^{d .75}$ per day) = 1.19 DDM (g/day) $-2.89\left(\mathrm{~s} . e . b=0.15 ; r^{2}=0.77\right)$. The similarity between the error terms for these equations indicates that body size did not affect the relationship between DDM and UAN.

\section{Discussion}

Agricultural Research Council (ARC, 1980) recommended an optimal ration of $1.34 \mathrm{~g}$ RDN per MJ ME (thus $1.34 \mathrm{~g} \mathrm{MiN} \mathrm{per} \mathrm{MJ} \mathrm{ME)} \mathrm{based} \mathrm{on} \mathrm{results}$ of trials conducted mostly close to maintenance with conventional diets where 0.65 of the digestible organic matter is assumed to be digested in the rumen. These results indicate that RDN from both diets was being used with equal efficiency for MiN synthesis despite the extreme difference between the two in the ratio QDN : RDN. EPM contains much 'apparent' QDN as uric acid which may release ammonia more slowly than urea. Alternatively, ARC (1980) may be correct in their assumption that when RDN is limiting, both QDN and SDN may be incorporated into $\mathrm{MiN}$ at an efficiency of 1.0.

When purine salvage and endogenous loss are constant, an increment of $1 \mathrm{~g}$ UAN corresponds to an increment of $17 \mathrm{~g}$ in MiN (Dewhurst, 1989). Applying this factor to equation 1, the yield of MiN becomes $20 \mathrm{~g} / \mathrm{kg} \mathrm{DDM}$, or $1.4 \mathrm{~g}$ MiN per M] ME. This is entirely consistent with the ARC (1980) estimate of the efficiency of microbial yield in circumstances where RDN is limiting. Since the nominal ratio of
RDN : ME for the two diets was $1.3: 1.0$, these results imply an efficiency of capture of RDN of 1.07, not significantly different from 1.0 , although efficiencies in excess of 1.0 (i.e. incorporation of endogenous nitrogen) are to be expected when RDN is limiting.

\section{References}

Agricultural Research Council. 1980. The nutrient requirenents of farm livestock. No. 2 Ruminants. 2nd ed. Commonwealth Agricultural Bureaux, Farnham Royal.

Chen, X. B., Hovell, F. D. De B., Orskov, E. R. and Brown, D. S. 1990. Excretion of purine derivatives by ruminants: effect of exogenous nucleic acid supply on purine derivative excretion by sheep. British Journal of Nutrition 63: 131-142.

Dewhurst, R. J. 1989. Studies on energy and nitrogen metabolism in the rumen: investigation of less invasive techniques for these studies. Ph.D. thesis, University of Bristol.

Dewhurst, R. J. and Webster, A. J. F. 1992 . Effects of diet, level of intake, sodium bicarbonate and monensin on urinary allantoin excretion in sheep. British Journal of Nutrition.

Webster, A. J. F. 1989. Metabolisable protein -the UK approach. In CEC EUR 10657, pp. 47-54 